\title{
Impact of the COVID-19 Pandemic on Older Adults: Rapid Review
}

Audrey Lebrasseur ${ }^{1,2}$, MOT; Noémie Fortin-Bédard ${ }^{1,3}$; Josiane Lettre ${ }^{1}$, MSc, MOT; Emilie Raymond ${ }^{1,3}$, PhD; Eve-Line Bussières $^{1,4}, \mathrm{PhD}$; Nolwenn Lapierre ${ }^{1,2}, \mathrm{PhD}$; Julie Faieta ${ }^{1,2}, \mathrm{PhD}$; Claude Vincent ${ }^{1,2}, \mathrm{PhD}$; Louise Duchesne ${ }^{1,5}, \mathrm{PhD}$; Marie-Christine Ouellet ${ }^{1,6}, \mathrm{PhD}$; Eric Gagnon ${ }^{7,8}, \mathrm{PhD}$; André Tourigny ${ }^{7,9}$, MD; Marie-Ėve Lamontagne ${ }^{1,2}, \mathrm{PhD}$; François Routhier ${ }^{1,2}, \mathrm{PhD}$

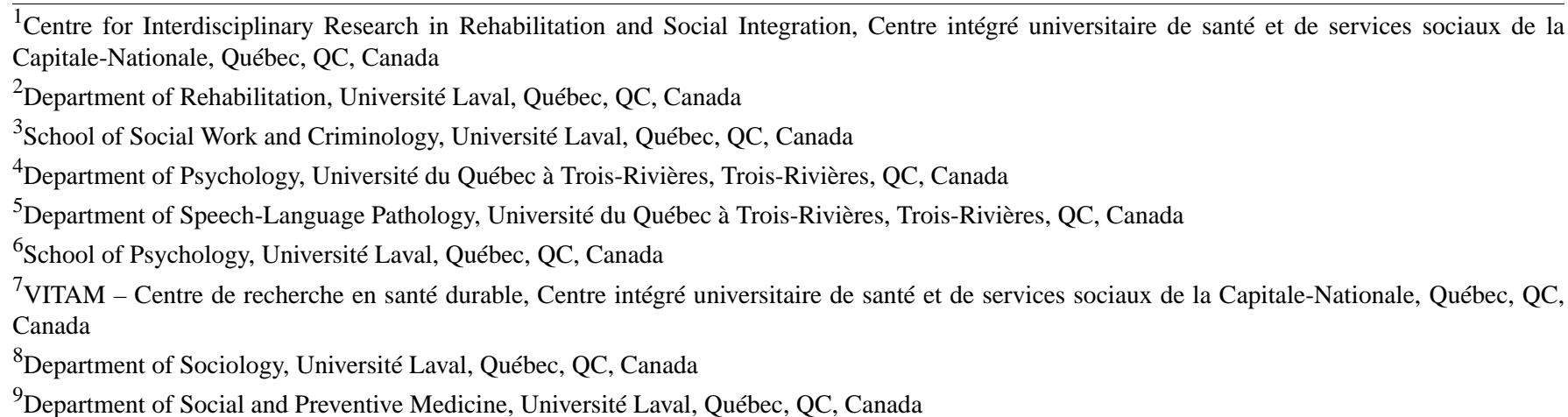

\section{Corresponding Author:}

François Routhier, $\mathrm{PhD}$

Centre for Interdisciplinary Research in Rehabilitation and Social Integration

Centre intégré universitaire de santé et de services sociaux de la Capitale-Nationale

525 Hamel est

Québec, QC, G1M 2S8

Canada

Phone: 14185299141 ext 6256

Email: francois.routhier@ rea.ulaval.ca

\section{Abstract}

Background: The COVID-19 pandemic has drastically changed the lives of countless members of the general population. Older adults are known to experience loneliness, age discrimination, and excessive worry. It is therefore reasonable to anticipate that they would experience greater negative outcomes related to the COVID-19 pandemic given their increased isolation and risk for complications than younger adults.

Objective: This study aims to synthesize the existing research on the impact of the COVID-19 pandemic, and associated isolation and protective measures, on older adults. The secondary objective is to investigate the impact of the COVID-19 pandemic, and associated isolation and protective measures, on older adults with Alzheimer disease and related dementias.

Methods: A rapid review of the published literature was conducted on October 6, 2020, through a search of 6 online databases to synthesize results from published original studies regarding the impact of the COVID-19 pandemic on older adults. The Human Development Model conceptual framework-Disability Creation Process was used to describe and understand interactions between personal factors, environmental factors, and life habits. Methods and results are reported following the Preferred Reporting Items for Systematic Reviews and Meta-analyses Statement.

Results: A total of 135 records were included from the initial search strategy of 13,452 individual studies. Of these, $113(83.7 \%)$ studies were determined to be of level 4 according to the levels of evidence classification by the Centre for Evidence-Based Medicine. The presence of psychological symptoms, exacerbation of ageism, and physical deterioration of aged populations were reported in the included studies. Decreased social life and fewer in-person social interactions reported during the COVID-19 pandemic were occasionally associated with reduced quality of life and increased depression. Difficulties accessing services, sleep disturbances, and a reduction of physical activity were also noted.

Conclusions: Our results highlight the need for adequate isolation and protective measures. Older adults represent a heterogeneous group, which could explain the contradictory results found in the literature. Individual, organizational, and institutional strategies 
should be established to ensure that older adults are able to maintain social contacts, preserve family ties, and maintain the ability to give or receive help during the current pandemic. Future studies should focus on specific consequences and needs of more at-risk older adults to ensure their inclusion, both in public health recommendations and considerations made by policy makers.

(JMIR Aging 2021;4(2):e26474) doi: 10.2196/26474

\section{KEYWORDS}

COVID-19; impact; rapid review; older adults; aged individuals; review

\section{Introduction}

\section{Background}

Since the end of 2019, the SARS-CoV-2 outbreak has resulted in more than 71 million cases worldwide, as of December 16, 2020 [1]. Isolation and protective measures have been established by governments to varying extents around the world in order to mitigate the spread of the virus. These measures include physical distancing, use of face masks, handwashing, stay-at-home policies, and restrictions on social gatherings [2,3]. As a result, the general population has experienced drastic changes in day-to-day life [4]; high COVID-19-related fear [5]; and numerous psychological outcomes such as depression [6], increased sleep problems [7], and financial worries [8].

However, the extent to which the effects of COVID-19 reported by the general population are experienced by the aging population is not well documented. Isolation and protective measures are crucial for the aging population, who are at greater risk of COVID-19-related death [9]. However, isolation and protective measures may also amplify issues that are already present in older adults, such as loneliness, age discrimination, and excessive worrying [10-12]. Considering that physical distancing inevitably leads to some degree of social isolation, speculation towards the pernicious impact of physical distancing on the mental health, daily activities [12], and cognitive decline of older adults [11] is warranted. The COVID-19 pandemic may also amplify age discrimination by negatively impacting access to information, health care services, and support to informal caregivers and familial advocates $[13,14]$.

According to the existing literature, although many older adults are now online $[15,16]$, the majority still need assistance when using digital technologies and to access and assess information [17]. Furthermore, most vulnerable older adults do not have access to web resources or the required digital skills and knowledge for its use to be satisfying and efficient $[15,18]$. Digital technology is thus insufficient to reach vulnerable populations such as older adults [19].

The fear of contracting the virus could be an additional source of concern for this population, thus contributing to the overall anxiety - a mental health outcome already known to negatively affect the quality of life in older adults [10]. Thus, it is possible that the immediate and long-term effects of the COVID-19 pandemic are heightened for older adults as compared to other age demographics.

Since the beginning of the pandemic, there has been substantial concern surrounding older adults living in nursing home [20]. The percentage of nursing home residents with Alzheimer disease or other types of dementia is significant, reported to range between $45 \%$ and $75 \%$ [21-23]. It is possible that people with Alzheimer disease or other dementias are experiencing greater negative outcomes related to the COVID-19 pandemic.

A better understanding of the unique experiences of older adults during the pandemic is needed in order for governing bodies and health care providers to design adequate policies [13] and services as we advance. Therefore, data specific to the needs of older adults within the context of the present COVID-19 pandemic are urgently needed.

\section{Objectives}

The aim of this study is to synthesize the existing research on the impact of the COVID-19 pandemic, and associated isolation and protective measures, on older adults. Furthermore, we aim to investigate the impact of the COVID-19 pandemic, and associated isolation and protective measures, on older adults with Alzheimer disease and related dementias.

\section{Methods}

\section{Protocol}

Given the urgent need for adequate information, a rapid review protocol was chosen. This type of review is conducted using an accelerated systematic review method, which limits certain aspects of the methodology in order to provide evidence within a policy maker's timeframe $[24,25]$. This approach aligns with the available guidance for Cochrane Rapid Review Methods Group [25] and with the Practical Guide for Rapid Reviews to Strengthen Health Policy and Systems [26]. Methods and results are reported following the PRISMA (Preferred Reporting Items for Systematic Reviews and Meta-analyses) Statement [27]. The protocol for the present review was registered within the PROSPERO database (ID: CRD42020201814).

\section{Conceptual Framework}

The Human Development Model-Disability Creation Process (HDM-DCP) conceptual framework was used to describe and understand interactions between personal factors, environmental factors, and life habits [28]. The HDM-DCP model acknowledges the impact of the environment and the person on the execution of life habits. Personal factors include identity (facilitator or obstacle), organic systems (integrity or impairment), and capabilities (ability or disability). Environmental factors are stratified into societal (facilitator or obstacle), community (facilitator or obstacle), and personal (facilitator or obstacle) levels. Life habits consist of daily activities (social participation situation or disabling situation) and social roles (social participation situation or disabling situation). Each of these elements can be seen as a protective factor or as a risk factor for the individual. The HDM-DCP 
framework allows observation of changes in these domains over a period of time (eg, the span of the COVID-19 pandemic). The framework puts into evidence social participation and social contacts, both of which may be greatly affected by pandemic-related isolation and protective measures.

\section{Literature Search}

Search strategies were developed by two authors (AL and NFB) and reviewed by two other authors (FR and ML). These strategies centered around three concepts: "COVID-19," "older adults," and "impact." The concept "COVID-19" was used to restrict the obtained results to those related to the present pandemic. According to the World Health Organization [29], older adults include people of 60 years of age and older. Therefore, in this study, the concept "older adults" included people aged 60 years and older, without excluding any diagnoses or conditions. The concept "impact" encompasses all three domains of the HDM-DCP model (ie, personal factors, environmental factors, and life habits) [28]. "Impact" variables can be reported by an individual, caregivers, family members, or health care workers, and may vary in the way that they are experienced or perceived. The following databases were used: MEDLINE via PUBMED; Embase, PsycINFO, and PsycARTICLES via Psycnet; and CINAHL and Ageline via
EBSCOhost. The searches were conducted on October 6, 2020. See Multimedia Appendix 1 for detailed search strategies used for each database.

\section{Eligibility Criteria}

The Population, Exposure, Comparator, and Outcomes (PECO) framework was used to develop the eligibility criteria used for the purposes of this review (see Table 1) [30]. Eligibility criteria were defined as follows: (1) peer-reviewed original papers with data related to our research question (opinion papers, reviews, methodological articles, preprints, and unpublished documents were excluded); (2) publication dates limited to 2019 and 2020 , as the COVID-19 outbreak was first reported in 2019; (3) papers available in English or French; and (4) participants 60 years of age and older with any diagnosis except for COVID-19 survivors. The fourth criterion was applied in order to differentiate the effect of the pandemic from the physiological and health-related outcomes associated with a COVID-19 diagnosis. Furthermore, only papers that specified in the abstract the inclusion of older adults in the study were included. Outcomes that did not fit into the domains of the HDM-DCP framework (eg, knowledge about the spread of the disease) were excluded.

Table 1. Population, Exposure, Comparator, and Outcomes inclusion criteria.

\begin{tabular}{ll}
\hline Component & Description \\
\hline Population (P) & People aged 60 years and older, excluding COVID-19 survivors \\
Exposure (E) & COVID-19 and its associated isolation and protective measures \\
Comparator (C) & Other age groups, before the pandemic, or none \\
Outcomes (O) & $\begin{array}{l}\text { Personal factors such as identity factors (facilitator or obstacle), organic systems (integrity or impairment), and } \\
\text { capabilities (ability or disability) }\end{array}$ \\
Environmental factors such as societal (facilitator or obstacle), community (facilitator or obstacle), and personal \\
(facilitator or obstacle) levels \\
Life habits such as daily activities (social participation situation or disabling situation) and social roles (social \\
participation situation or disabling situation)
\end{tabular}

\section{Study Selection and Data Extraction}

Data retrieved from the databases were exported to Covidence [31]. Two reviewers independently screened the titles and abstracts of the obtained records. These reviewers then read the full text of the selected papers and determined whether they should be included. Any disagreement was resolved via consensus. Next, a single reviewer completed data extraction, which was then verified by another reviewer. The following variables were extracted: title, year of publication, country, study design, objectives, participant characteristics (eg, diagnosis and age), and outcomes. The references of the included papers were screened by the reviewers (one reviewer per study), and the titles and abstracts of additional papers were screened if relevant.

\section{Level of Evidence Appraisal and Data Synthesis}

Two reviewers established the level of evidence for each selected study, based on the levels of evidence classification of the Centre for Evidence-Based Medicine [32]. Due to the limited turnaround time, no risk of bias assessment was performed. A narrative approach consistent with the data synthesis of a rapid review [24] was used.

\section{Results}

\section{Literature Search}

The search strategy identified 19,053 records. A total of 13,452 records remained after duplicates $(n=5601)$ were removed. Upon title and abstract screening, the number of papers reduced to 630 , after the exclusion of 12,822 records. Thereafter, full-text screening resulted in a final inclusion of 135 records (Figure 1), following the exclusion of 495 others for various reasons. 
Figure 1. PRISMA (Preferred Reporting Items for Systematic Reviews and Meta-analyses) flow diagram.

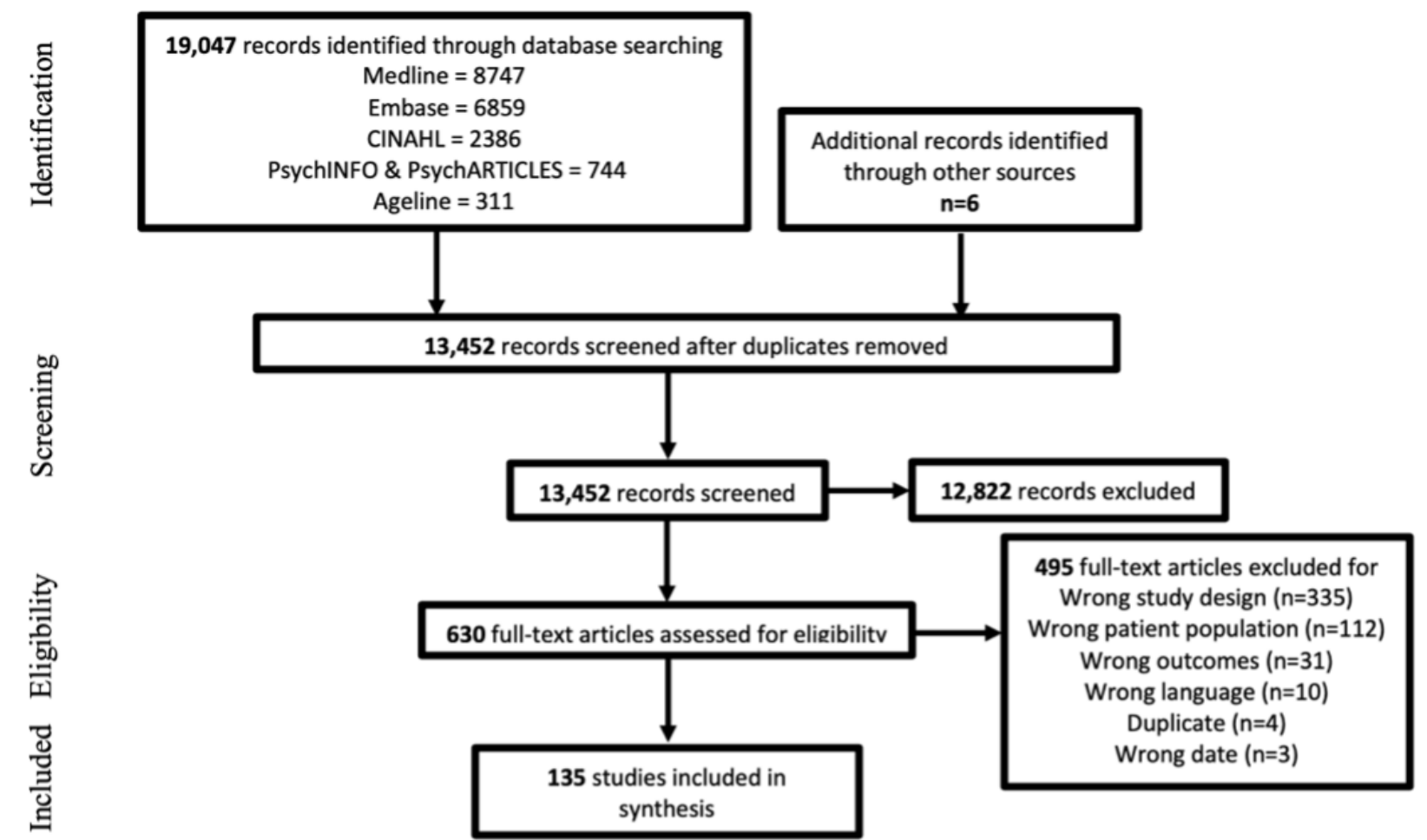

\section{Characteristics of Included Studies}

The selected records and their corresponding levels of evidence are shown in Table S1 of Multimedia Appendix 2. In all, 113 of $135(83.7 \%)$ studies were determined to be of level 4 according to the Centre for Evidence-Based Medicine-Levels of Evidence [32] (transversal data collection), 20 (14.8\%) studies were determined to be of level $2 \mathrm{~b}$ (longitudinal studies), and 2 $(1.5 \%)$ studies were of level $2 \mathrm{~b}$ and level 4 (mixed study designs).

Of the 135 studies included, 40 (29.7\%) studies included only older adults ( $\geq 60$ years old) whereas 95 (70.3\%) compared various age groups. Moreover, $15(11.1 \%)$ studies included persons with specific conditions such as Alzheimer disease [33-35], Parkinson disease [36], frontotemporal lobar degeneration [37], severe cognitive impairments [38], ovarian cancer [39], gynecological cancer [40], patients with cancer actively treated with systemic therapy [41], pre-existing depression [42], chronic conditions [43], long-term respiratory conditions [44], migraine [45], epilepsy [46], and visual impairments [47]. A total of 29 (21.5\%) studies were conducted in North America [40,42,43,48-73], $14(10.3 \%)$ in China [46,74-86], $61(45.1 \%)$ in Europe [33-38,41,44,87-139], 3 $(2.2 \%)$ in Japan [140-142], 4 (3.0\%) in Israel [143-146], 4 (3.0\%) in Brazil [147-150], 4 (3.0\%) in Australia [151-154], 2 $(1.5 \%)$ in India [155,156], $1(0.7 \%)$ in Malaysia [157], $2(1.5 \%)$ in Kuwait [45,158], $1(0.7 \%)$ in Saudi Arabia [159], 3 (2.2\%) in Argentina [160-162], 1 (0.7\%) in Cameroon [163], 1 (0.7\%) in Russia [164], $1(0.7 \%)$ in Ghana [47], 1 (0.7\% in Cyprus [165], and $3(2.2 \%)$ in multiple countries $[39,166,167]$.

\section{Outcomes of Included Studies}

\section{Personal Factors}

Older adults reported a presence or worsening of psychological symptoms, and greater loneliness because of pandemic-related social isolation $[33,38,47,49,51,52,56,57,62,63,77,78$, $84,89,90,99,105,114,117,128,135,139,140,148,156,160]$. Compared to younger age, older age (ie, $\geq 60$ years) was, however, associated with fewer psychological symptoms $[39,44,50,54,57,59,64-67,74,77,89,95,97,98,101,107,109,111,114,116$, $120,121,124,125,127,136,138,147,151,153,157,158,161,162,165]$, lower loneliness [92,95,104,130,140,159], and better mental health and well-being [95,106,126,157,161,162]. Older adults were also shown to be better at regulating their emotions and coping with stressful events $[44,61,68]$. In contrast, $6(4.4 \%)$ studies reported that older adults had more severe psychological symptoms than participants of other age groups $[83,85,86,96,118,156]$, and some studies noted no psychological symptoms for most participants $[42,79,119,165]$.

Several variables were associated with poor psychological health and well-being, including living alone [117], decreased social interactions [88], feeling close to death, high levels of COVID-19-related health worries [145], stress [70], health concerns and ageism [143], not having cognitive impairments [38], and male status [78]. In contrast, religious faith, exercise, self-care, and time spent in nature were associated with positive psychological well-being [70].

Various worries surrounding the current pandemic were reported in these studies $[36,49,105,107,110,155]$. For instance, older adults were more worried about COVID-19 [68,75,96,118,167], whereas younger individuals were more concerned about the 
risks related to social isolation [164]. Older adults were less concerned for their emotional well-being, work goals, and finances [65], and they perceived they had lower chances of "running out of money" [53]. However, more worries about financial difficulties were reported in another study [164]. Older adults perceived the risks of COVID-19 (in comparison to that of the flu) to be higher $[48,138]$, but aged men were less worried about COVID-19 (eg, contracting the virus, dying due to COVID-19, or disruptions to lifestyle) than their younger counterparts [48]. Their concerns were focused on others rather than themselves [144]. Anxiety associated with cancer was lower in older adults than in younger adults [41]. Expectations (eg, income decline, duration and long-term impact of COVID-19) were associated with an experience of stress, which was further associated with other negative effects [69]. Finally, the passage of time during the pandemic was found to be slower for older adults [115].

Regarding the impairment of organic systems, higher age was associated with poorer health status [80] and in some cases, a decline of functional status [163]. Decreases in mobility, functionality, vitality, and physical conditions were also noted [36,148]. An aggravation in neuropsychiatric and physical symptoms was reported in individuals with Alzheimer disease, dementia, and frontotemporal lobar degeneration, as well as in nursing home residents $[34,35,37,93,139]$. An exacerbation of migraine days and severity was observed among individuals with a migraine diagnosis [45]. One out of six older patients with epilepsy experienced increased seizures, but this frequency increased considerably among younger people with epilepsy [46].

\section{Environmental Factors}

Decreased social life and fewer in-person social interactions observed during the pandemic were occasionally associated with reduced quality of life and increased depression $[42,63,128,139]$. Some individuals continued to meet their relatives almost daily [36]. Furthermore, some studies reported on the negative impacts of the pandemic for caregivers [34,35].

Older adults reported unmet personal, domestic, or social needs [128]; difficulty finding help with functional needs such as bathing [62]; insufficient personal care [139]; decreased care rendered by caregivers [47]; and reductions in social support services hours [99]. Multiple barriers to care delivery were noted during this time [166]. For instance, one study reported that older adults were more likely to miss or cancel medical appointments [129], whereas another reported the opposite [60]. One study reported that treatment delays and postponed appointments were more common among older adults [130], whereas another reported this was more commonly observed among younger people [40]. More patients missed medical appointments during the pandemic as compared to the prepandemic timepoints [84,163], and rehabilitation services were discontinued for the majority due to the quarantine [160]. Finally, as compared to the previous years, psychiatry consultations for older individuals had reduced in one study [113] but reported to have increased in another [76]

\section{Life Habits}

Changes in sleep habits and sleep disturbances were reported to be affected by COVID-19 [37,56,84,87,105,134,160]. Of note, some studies indicated that sleep issues were lower in older adults than in younger adults [122,134,147].

Older adults reported a lower increase in unhealthy food intake, screen use, tobacco use [149], alcohol use [149,154], and cannabis use than did younger adults $[123,152]$, in addition to a lower rise in unhealthy lifestyle changes or drinking [131]. One study indicated that the majority of older individuals consumed a balanced diet, limited their alcohol intake, and had adequate sleep patterns [82], whereas another study reported no change in alcohol use patterns [71]. This finding was contrasted by other studies that found that older adults increased binge drinking, alcohol frequency, alcohol consumption, and cigarette smoking [56,114,132]; changed their eating habits $[132,148]$; ate more [56,87]; and ate more often [87]. One study reported a higher consumption of unhealthy foods among older adults, as compared with participants of other age groups [149]. Food insufficiency increased in older adults during the pandemic, but to a lesser extent than that among younger adults [73], and decreased care resulted in hunger [47].

Changes in daily routine and plans were reported in a few studies $[43,52,58]$; however, one study noted no changes in the performance of daily habits among older adults [102]. Behavioral changes, such as buying more food and water than usual, going out less frequently, reducing social contacts, and staying away from public places were noted in several studies $[36,47,58,146]$. Unemployment increased in older adults, but at a lower rate than that in other age groups [72]. Higher age was associated with fewer sexual activities [108]. Some studies reported a decrease in physical activity [56,132,141,142,149] and a decline in attendance at physical activity workshops [133]. However, studies reported contradictory results regarding physical activity among older adults during the pandemic. Indeed, it was noted that older adults had the lowest levels of physical activity among all age groups [55,100]; however, they had the smallest decrease in physical activity [100], the lowest prevalence of insufficient physical activity [81] and were less likely to have changed their physical activity levels during the pandemic [137]. Moreover, physical activity was associated with higher resilience, positive affect, and lower depressive symptoms [94,141]. Older adults were also reported to have a lesser change in unhealthy movement behaviors [150].

A study indicated that a lot of time was spent learning about COVID-19 [87], and more time was spent using social media [56], internet [144], and electronic products [150]. One study reported a higher usage of electronic products by older people [149], whereas others reported contrasting findings [74,81]. Participants felt blessed, lucky, and fortunate to be able to stay in contact with others through social media [91]. Variation in game use by older adults did not differ from that observed in younger populations [167]. Older adults had fewer positive work events but more remote social interactions, social networks, and outdoor activities [65]. Finally, older adults engaged in more solitary activities and in fewer in-person activities [56]. 
One study reported that the majority of older adult travelers were planning to travel by air in the next year [103], whereas another found that older adults were canceling out-of-town trips [58]. The COVID-19 pandemic has presented significant challenges to most older adults [58], and compliance to hygiene recommendations was seen as a psychological burden by this population [148].

\section{Discussion}

\section{Principal Results}

Older adults are known to experience loneliness, age discrimination, and excessive worrying [10-12]. Therefore, we initially anticipated that they would experience greater negative outcomes related to the COVID-19 pandemic. However, this hypothesis was not uniformly supported by the available literature. The findings summarized within this review suggest that older adults experienced negative outcomes related to the pandemic, but to a lesser extent than their younger counterparts. Younger adults experienced greater psychological repercussions from isolation and feeling of loneliness [168]. There was indeed a correlation between young age and poor mental health [126], higher anxiety, depression, and stress [153]. This result may be explained by the daily experience of loneliness and social isolation among older adults prior to the pandemic [12], which in turn meant that COVID-19 led to fewer changes in their daily routine as compared to employed, younger adults. Another potential explanation is the influence of certain personal factors among older adults, for example, greater resilience that is associated with more purpose in life [112], better regulation of emotions, and better coping strategies in the case of stressful events $[44,61,68]$. These personal factors could explain the generally better psychological response by older adults throughout the COVID-19 pandemic. Additionally, these findings may be explained by sampling methods used in the available research. In other words, the isolation measures implemented in long-term care facilities may have caused additional barriers to conducting studies with residents. In our study sample, $16(11.8 \%)$ studies were conducted among community dwelling older adults, $3(2.2 \%)$ included older adults living in residential care facilities, $3(2.2 \%)$ included older adults living in one of these two locations, and 113 (83.7\%) studies did not detail this sampling information. Without uniform sampling methods, it is more difficult to draw strong conclusions. Older adults may have little to no access to technology [169], such as a computer or a smartphone, which are often required to participate in web-based surveys. The most isolated individuals may be the most difficult to reach, particularly if they lack access to social media or maintain minimal presence in public and community organizations-platforms often used by researchers to contact participants. Fewer opportunities to participate in surveys may explain the relative scarcity of research on vulnerable older adult populations, such as those with dementia or Alzheimer disease, during the present pandemic. In studies that compared different age groups, the proportion of aged individuals was often very small compared to other age groups. It is possible that the older adults who participated in surveys were healthy and had access to technology and, therefore, were not the most vulnerable. This could explain why certain studies suggested that younger people were more impacted than older adults.

One study reported that anxiety symptoms in older adults were associated with ageism [143], something that the current pandemic seems to have exacerbated [170]. The COVID-19 pandemic has been characterized as an older adult problem, and social media, among other platforms, have been used by people to share ageist attitudes (eg, posts published with the hashtag "BoomerRemover") [171-173]. Greater awareness of age discrimination is needed to reduce these behaviors. There are other potential sources of anxiety among older adults, such as being unable to access support services since the onset of the COVID-19 pandemic [99]. More research is needed to understand the impact of ageism on older adults' well-being, as compared with other risk factors.

The impact of the pandemic on older adults can also influence their caregivers [34,35]. Indeed, family caregivers reported living with anxiety and fear [174] and having difficulty balancing caregiving challenges with their own needs [175] during this crisis. It is therefore important to consider the needs of the caregivers in future policies and in the implementation of isolation and protective measures.

The available literature offered different strategies for maintaining the well-being of older adults; these included using technology to ensure social connections, pursuing outdoor activities, and incorporating daily structure [176]. Different programs were also deployed during the pandemic with the aim of reducing social isolation through contact with a student volunteer who engaged in weekly phone calls with participants living in nursing homes [177] and a single call with participants living in long-term care facilities and in the community [178]. The use of technology to protect and improve mental health [179] and to maintain the health and independence [180] of older adults during this crisis was also discussed. The transformation of an on-site program into an online program for older populations [181] was found to be effective. Innovative programs should therefore be created with the goal of supporting vulnerable older adults and minimizing the long-term consequences and feelings of loneliness.

Physical activity should be promoted during the pandemic, especially for more at-risk individuals such as those living with chronic diseases [182]. Older adults should be guided to safe and accessible physical activity programs, selected according to the individual's level of autonomy, mobility, frailty, and health status, to avoid deconditioning during confinement. Physical activity is associated with a better quality of life [183] and decreased symptoms of depression in older adults [50], whereas increased inactivity could accelerate their physical decline [184]. Personalized physical activity programs with monitoring should therefore be made more accessible to this population to minimize deconditioning and help older adults maintain their physical and mental health, while ensuring their safety.

The secondary impacts of COVID-19 should be considered by governing bodies and institutions when taking action and making decisions about health care access and public health measures, both during the current pandemic and for future health crisis. 
Mental health concerns have been reported among older adults [185], but few concrete actions have been taken to mitigate them.

\section{Strengths and Limitations}

Some studies classified older adults as including people below 60 years of age (eg, $\geq 50$ years) [186-188]. Those results were excluded, along with potentially important data, to respect our eligibility criteria and to clearly differentiate the outcomes relative to older versus younger populations. Moreover, some studies focused on older adults with specific conditions, for example, Parkinson disease [36], cancer [39,40] or Alzheimer disease [33], which makes it difficult to differentiate the effects associated with their age from those associated with their condition. These studies were still analyzed, keeping in mind that individuals living with a variety of diagnoses are potentially more vulnerable to encounter negative outcomes related to the secondary effects of COVID-19. Some diagnostic keywords were selected because of the relationship between specific neurological conditions and higher age (eg, dementia and Alzheimer disease). This selection may have resulted in the omission of eligible studies that include older adults with other conditions such as cancer or cardiovascular diseases. However, a limitation in the selected keywords was needed to screen studies within a reasonable timeframe. In addition, the decision was made to exclude studies about COVID-19 survivors, because of the various physical and psychological changes that may be associated with the incidence of this condition. Contradictory results could also be attributable to the variance in health care systems and differences in isolation and protective measures implemented in various countries. Because of constant changing measures across countries, it would have been difficult, if not impossible, to analyze data in such a way. This aspect was, therefore, not considered in our data analysis in order to provide results in a reasonable timeframe. Future studies should take into consideration the country-specific variation in COVID-19 responses. Moreover, it is also possible that the sample age was not mentioned in the abstract or the title of the published papers, which would have resulted in the exclusion of the study during the first stage of screening.

\section{Implication for Practice and Policy}

Results obtained through this rapid review have highlighted the presence of psychological symptoms, decrease in social interactions, exacerbation of ageism, and the deterioration of physical conditions among older adult populations during the COVID-19 pandemic. It is essential that governing bodies and decision makers understand the needs of older adults when making choices regarding the implementation of social distancing measures. They should carefully choose their words when describing this pandemic, to avoid any form of age discrimination in the media.

Older adults represent a heterogeneous group, which could explain the contradictory results found in the sampled literature. Sample demographics should be considered in future studies to identify variables within older adult populations that could be associated with a poorer overall experience with the pandemic, and stronger conclusions could then be made. Indeed, studies that specifically target vulnerable age groups, such as adults living in rural areas [189] and deaf individuals [190], should be conducted to minimize the effects and long-term consequences in such populations. The impact of COVID-19 should be assessed separately according to various living environments in order to identify more at-risk individuals (eg, older adults in the community setting versus long-term care facilities). Future studies should also analyze different protective and risk factors among older adults. For example, it would be interesting to compare the effect of living alone versus living with others, of being in the younger range of the older adult demographic (eg, 60 years old) versus being in the latter range (eg, 85 years old), or of living independently at home versus living in a nursing home. Moreover, the general population could learn from older adults, regarding their resilience, regulation of emotions, and coping strategies, to improve their psychological response during this pandemic. Individual, organizational, and institutional strategies should be established to ensure that older adults are able to maintain social contacts, preserve family ties, and maintain the ability to give or receive help during this pandemic. The effectiveness of various strategies, such as making communication technologies more accessible, providing technology use training, and promoting technological innovations, should also be assessed to enable social interactions despite isolation and protective measures.

\section{Acknowledgments}

This rapid review was funded by the Centre for Interdisciplinary Research in Rehabilitation and Social Integration (CIRRIS), and the Quebec Rehabilitation Research Network (REPAR) and the Quebec Research Network on Aging (RQRV), two thematic networks funded by the Health Quebec Research Fund (FRQS). AL, NFB, and JF are funded through a Mitacs scholarship. ML, EB, and FR are supported through a FRQS Research Scholar.

\section{Conflicts of Interest}

None declared.

\section{Multimedia Appendix 1}

Search strategies.

\section{[DOCX File, 23 KB-Multimedia Appendix 1]}




\section{Multimedia Appendix 2}

Table S1. Synthesis of the 135 selected studies and their level of evidence. [DOCX File, 113 KB-Multimedia Appendix 2]

\section{References}

1. WHO Coronavirus Disease (COVID-19) Dashboard. World Health Organization. URL: https://covid19.who.int/ [accessed 2021-03-26]

2. Baker MG, Wilson N, Anglemyer A. Successful Elimination of Covid-19 Transmission in New Zealand. N Engl J Med 2020 Aug 20;383(8):e56. [doi: 10.1056/nejmc2025203]

3. Chu DK, Akl EA, Duda S, Solo K, Yaacoub S, Schünemann HJ, COVID-19 Systematic Urgent Review Group Effort (SURGE) study authors. Physical distancing, face masks, and eye protection to prevent person-to-person transmission of SARS-CoV-2 and COVID-19: a systematic review and meta-analysis. Lancet 2020 Jun 27;395(10242):1973-1987 [FREE Full text] [doi: 10.1016/S0140-6736(20)31142-9] [Medline: 32497510]

4. El-Zoghby SM, Soltan EM, Salama HM. Impact of the COVID-19 Pandemic on Mental Health and Social Support among Adult Egyptians. J Community Health 2020 Aug;45(4):689-695 [FREE Full text] [doi: 10.1007/s10900-020-00853-5] [Medline: $\underline{\text { 32468155] }}$

5. Bäuerle A, Teufel M, Musche V, Weismüller B, Kohler H, Hetkamp M, et al. Increased generalized anxiety, depression and distress during the COVID-19 pandemic: a cross-sectional study in Germany. J Public Health (Oxf) 2020 Nov 23;42(4):672-678 [FREE Full text] [doi: 10.1093/pubmed/fdaa106] [Medline: 32657323]

6. Alkhamees AA, Alrashed SA, Alzunaydi AA, Almohimeed AS, Aljohani MS. The psychological impact of COVID-19 pandemic on the general population of Saudi Arabia. Compr Psychiatry 2020 Oct;102:152192 [FREE Full text] [doi: 10.1016/j.comppsych.2020.152192] [Medline: $\underline{\text { 32688022] }}$

7. Beck F, Léger D, Fressard L, Peretti-Watel P, Verger P, Coconel Group. Covid-19 health crisis and lockdown associated with high level of sleep complaints and hypnotic uptake at the population level. J Sleep Res 2021 Feb;30(1):e13119 [FREE Full text] [doi: 10.1111/jsr.13119] [Medline: $\underline{\text { 32596936] }}$

8. Chakraborty K, Chatterjee M. Psychological impact of COVID-19 pandemic on general population in West Bengal: A cross-sectional study. Indian J Psychiatry 2020 May 15;62(3):266-272. [doi: 10.4103/psychiatry.indianjpsychiatry 276 20]

9. Williamson EJ, Walker AJ, Bhaskaran K, Bacon S, Bates C, Morton CE, et al. Factors associated with COVID-19-related death using OpenSAFELY. Nature 2020 Aug;584(7821):430-436. [doi: 10.1038/s41586-020-2521-4] [Medline: 32640463$]$

10. Golden J, Conroy RM, Bruce I, Denihan A, Greene E, Kirby M, et al. The spectrum of worry in the community-dwelling elderly. Aging Ment Health 2011 Nov;15(8):985-994. [doi: 10.1080/13607863.2011.583621] [Medline: 21749221]

11. Griffin SC, Mezuk B, Williams AB, Perrin PB, Rybarczyk BD. Isolation, Not Loneliness or Cynical Hostility, Predicts Cognitive Decline in Older Americans. J Aging Health 2020;32(1):52-60. [doi: 10.1177/0898264318800587] [Medline: 30289338]

12. Singh A, Misra N. Loneliness, depression and sociability in old age. Ind Psychiatry J 2009 Jan;18(1):51-55 [FREE Full text] [doi: 10.4103/0972-6748.57861] [Medline: 21234164]

13. Buchanan J. Protect Rights of People with Disabilities During COVID-. New York: Human Rights Watch; 2020 Mar 26. URL: https://www.hrw.org/news/2020/03/26/protect-rights-people-disabilities-during-covid-19 [accessed 2021-03-26]

14. Lyons A, Alba B, Heywood W, Fileborn B, Minichiello V, Barrett C, et al. Experiences of ageism and the mental health of older adults. Aging Ment Health 2018 Nov;22(11):1456-1464. [doi: 10.1080/13607863.2017.1364347] [Medline: 28795587]

15. Schumacher S, Kent N. 8 charts on internet use around the world as countries grapple with COVID-19. Pew Research Center. 2020 Apr 02. URL: https://www.pewresearch.org/fact-tank/2020/04/02/ 8-charts-on-internet-use-around-the-world-as-countries-grapple-with-covid-19/ [accessed 2021-03-26]

16. Anderson M, Perrin A, Kumar M. 10\% of Americans don't use the internet. Who are they? Pew Research Center. 2019 Apr 22. URL: https://www.pewresearch.org/fact-tank/2019/04/22/some-americans-dont-use-the-internet-who-are-they/ [accessed 2021-03-26]

17. Anderson M, Perrin A. Tech Adoption Climbs Among Older Adults. Pew Research Center. 2017 May 17. URL: https:/ /www.pewresearch.org/internet/2017/05/17/tech-adoption-climbs-among-older-adults/ [accessed 2021-03-26]

18. Son JS, Nimrod G, West ST, Janke MC, Liechty T, Naar JJ. Promoting Older Adults' Physical Activity and Social Well-Being during COVID-19. Leisure Sciences 2020 Jun 26:1-8. [doi: 10.1080/01490400.2020.1774015]

19. Xie B, Charness N, Fingerman K, Kaye J, Kim MT, Khurshid A. When Going Digital Becomes a Necessity: Ensuring Older Adults' Needs for Information, Services, and Social Inclusion During COVID-19. J Aging Soc Policy 2020;32(4-5):460-470. [doi: 10.1080/08959420.2020.1771237] [Medline: $\underline{32507061]}$

20. Simard J, Volicer L. Loneliness and Isolation in Long-term Care and the COVID-19 Pandemic. J Am Med Dir Assoc 2020 Jul;21(7):966-967 [FREE Full text] [doi: 10.1016/j.jamda.2020.05.006] [Medline: $\underline{\text { 32505516] }}$

21. Lolk A, Andersen K. Prevalence of depression and dementia among nursing home residents [Article in Danish]. Ugeskr Laeger 2015 Mar 16;177(12):V11140591. [Medline: 25786839] 
22. Gaugler JE, Yu F, Davila HW, Shippee T. Alzheimer's disease and nursing homes. Health Aff (Millwood) 2014 Apr;33(4):650-657 [FREE Full text] [doi: 10.1377/hlthaff.2013.1268] [Medline: 24711327]

23. Wong SL, Gilmour H, Ramage-Morin PL. Alzheimer's disease and other dementias in Canada. Health Rep 2016 May 18;27(5):11-16 [FREE Full text] [Medline: 27192206]

24. Grant M, Booth A. A typology of reviews: an analysis of 14 review types and associated methodologies. Health Info Libr J 2009 Jun;26(2):91-108 [FREE Full text] [doi: 10.1111/j.1471-1842.2009.00848.x] [Medline: 19490148]

25. Garritty C, Gartlehner G, Nussbaumer-Streit B, King VJ, Hamel C, Kamel C, et al. Cochrane Rapid Reviews Methods Group offers evidence-informed guidance to conduct rapid reviews. Journal of Clinical Epidemiology 2021 Feb;130:13-22. [doi: 10.1016/j.jclinepi.2020.10.007]

26. World Health Organization, Alliance for Health Policy and Systems Research. In: Tricco AC, Langlois EV, Straus SE, editors. Rapid reviews to strengthen health policy and systems: a practical guide. Geneva: World Health Organization; 2017:119.

27. Moher D, Liberati A, Tetzlaff J, Altman DG, PRISMA Group. Preferred reporting items for systematic reviews and meta-analyses: the PRISMA statement. PLoS Med 2009 Jul 21;6(7):e1000097 [FREE Full text] [doi: 10.1371/journal.pmed.1000097] [Medline: 19621072]

28. The Model. International Network on the Disability Creation Process. URL: https://ripph.qc.ca/en/hdm-dcp-model/the-model/ [accessed 2021-03-26]

29. Ageing and health. World Health Organization. URL: https://www.who.int/news-room/fact-sheets/detail/ageing-and-health [accessed 2021-03-26]

30. Morgan RL, Whaley P, Thayer KA, Schünemann HJ. Identifying the PECO: A framework for formulating good questions to explore the association of environmental and other exposures with health outcomes. Environ Int 2018 Dec;121(Pt 1):1027-1031. [doi: 10.1016/j.envint.2018.07.015] [Medline: 30166065]

31. Reviewers. Covidence - Better systematic review management. URL: https://www.covidence.org/reviewers [accessed 2021-03-26]

32. Levels of Evidence 1. Oxford Centre for Evidence-based Medicine. 2009. URL: https://www.cebm.ox.ac.uk/resources/ levels-of-evidence/oxford-centre-for-evidence-based-medicine-levels-of-evidence-march-2009 [accessed 2021-03-26]

33. El Haj M, Altintas E, Chapelet G, Kapogiannis D, Gallouj K. High depression and anxiety in people with Alzheimer's disease living in retirement homes during the covid-19 crisis. Psychiatry Res 2020 Sep;291:113294 [FREE Full text] [doi: 10.1016/j.psychres.2020.113294] [Medline: 32763552]

34. Boutoleau-Bretonnière C, Pouclet-Courtemanche H, Gillet A, Bernard A, Deruet AL, Gouraud I, et al. The Effects of Confinement on Neuropsychiatric Symptoms in Alzheimer's Disease During the COVID-19 Crisis. J Alzheimers Dis 2020;76(1):41-47. [doi: 10.3233/JAD-200604] [Medline: 32568211]

35. Lara B, Carnes A, Dakterzada F, Benitez I, Piñol-Ripoll G. Neuropsychiatric symptoms and quality of life in Spanish patients with Alzheimer's disease during the COVID-19 lockdown. Eur J Neurol 2020 Sep;27(9):1744-1747 [FREE Full text] [doi: 10.1111/ene.14339] [Medline: $\underline{32449791]}$

36. Zipprich HM, Teschner U, Witte OW, Schönenberg A, Prell T. Knowledge, Attitudes, Practices, and Burden During the COVID-19 Pandemic in People with Parkinson's Disease in Germany. J Clin Med 2020 May 29;9(6):1643 [FREE Full text] [doi: 10.3390/jcm9061643] [Medline: 32486074]

37. Capozzo R, Zoccolella S, Frisullo M, Barone R, Dell'Abate M, Barulli M, et al. Telemedicine for Delivery of Care in Frontotemporal Lobar Degeneration During COVID-19 Pandemic: Results from Southern Italy. JAD 2020 Jul 21;76(2):481-489. [doi: 10.3233/jad-200589]

38. Van der Roest HG, Prins M, van der Velden C, Steinmetz S, Stolte E, van Tilburg TG, et al. The Impact of COVID-19 Measures on Well-Being of Older Long-Term Care Facility Residents in the Netherlands. J Am Med Dir Assoc 2020 Nov;21(11):1569-1570 [FREE Full text] [doi: 10.1016/j.jamda.2020.09.007] [Medline: 33036911]

39. Frey MK, Ellis AE, Zeligs K, Chapman-Davis E, Thomas C, Christos PJ, et al. Impact of the coronavirus disease 2019 pandemic on the quality of life for women with ovarian cancer. Am J Obstet Gynecol 2020 Nov;223(5):725.e1-725.e9 [FREE Full text] [doi: 10.1016/j.ajog.2020.06.049] [Medline: 32598911]

40. Frey MK, Fowlkes RK, Badiner NM, Fishman D, Kanis M, Thomas C, et al. Gynecologic oncology care during the COVID-19 pandemic at three affiliated New York City hospitals. Gynecol Oncol 2020 Nov;159(2):470-475 [FREE Full text] [doi: 10.1016/j.ygyno.2020.09.005] [Medline: $\underline{32981694]}$

41. Sigorski D, Sobczuk P, Osmola M, Kuć K, Walerzak A, Wilk M, et al. Impact of COVID-19 on anxiety levels among patients with cancer actively treated with systemic therapy. ESMO Open 2020 Oct;5(5):e000970 [FREE Full text] [doi: 10.1136/esmoopen-2020-000970] [Medline: 33097653]

42. Hamm M, Brown P, Karp J, Lenard E, Cameron F, Dawdani A, et al. Experiences of American Older Adults with Pre-existing Depression During the Beginnings of the COVID-19 Pandemic: A Multicity, Mixed-Methods Study. Am J Geriatr Psychiatry 2020 Sep;28(9):924-932 [FREE Full text] [doi: 10.1016/j.jagp.2020.06.013] [Medline: 32682619]

43. Bailey SC, Serper M, Opsasnick L, Persell SD, O'Conor R, Curtis LM, et al. Changes in COVID-19 Knowledge, Beliefs, Behaviors, and Preparedness Among High-Risk Adults from the Onset to the Acceleration Phase of the US Outbreak. J Gen Intern Med 2020 Nov;35(11):3285-3292 [FREE Full text] [doi: 10.1007/s11606-020-05980-2] [Medline: $\underline{\text { 32875509] }}$ 
44. Philip K, Cumella A, Farrington-Douglas J, Laffan M, Hopkinson N. Respiratory patient experience of measures to reduce risk of COVID-19: findings from a descriptive cross-sectional UK wide survey. BMJ Open 2020 Sep 09;10(9):e040951 [FREE Full text] [doi: 10.1136/bmjopen-2020-040951] [Medline: $\underline{32912958]}$

45. Al-Hashel JY, Ismail II. Impact of coronavirus disease 2019 (COVID-19) pandemic on patients with migraine: a web-based survey study. J Headache Pain 2020 Sep 24;21(1):115 [FREE Full text] [doi: 10.1186/s10194-020-01183-6] [Medline: 32972360]

46. Huang S, Wu C, Jia Y, Li G, Zhu Z, Lu K, et al. COVID-19 outbreak: The impact of stress on seizures in patients with epilepsy. Epilepsia 2020 Sep;61(9):1884-1893 [FREE Full text] [doi: 10.1111/epi.16635] [Medline: $\underline{\text { 32761900] }}$

47. Kwegyir Tsiboe A. Describing the experiences of older persons with visual impairments during COVID-19 in rural Ghana. JAP 2020 Sep 23;22(6):371-383 [FREE Full text] [doi: 10.1108/jap-07-2020-0026]

48. Barber SJ, Kim H. COVID-19 Worries and Behavior Changes in Older and Younger Men and Women. J Gerontol B Psychol Sci Soc Sci 2021 Jan 18;76(2):e17-e23 [FREE Full text] [doi: 10.1093/geronb/gbaa068] [Medline: 32427341]

49. Bruine DBW. Age Differences in COVID-19 Risk Perceptions and Mental Health: Evidence From a National U.S. Survey Conducted in March 2020. J Gerontol B Psychol Sci Soc Sci; 2020, May 2020 May 29:e24-e29. [doi: $10.1093 /$ geronb/gbaa074]

50. Callow DD, Arnold-Nedimala NA, Jordan LS, Pena GS, Won J, Woodard JL, et al. The Mental Health Benefits of Physical Activity in Older Adults Survive the COVID-19 Pandemic. Am J Geriatr Psychiatry 2020 Oct;28(10):1046-1057 [FREE Full text] [doi: 10.1016/j.jagp.2020.06.024] [Medline: $\underline{\text { 32713754] }}$

51. Callow M, Callow D, Smith C. Older Adults' Intention to Socially Isolate Once COVID-19 Stay-at-Home Orders Are Replaced With "Safer-at-Home" Public Health Advisories: A Survey of Respondents in Maryland. J Appl Gerontol 2020 Nov;39(11):1175-1183 [FREE Full text] [doi: 10.1177/0733464820944704] [Medline: $\underline{32697126]}$

52. Chen AT, Ge S, Cho S, Teng AK, Chu F, Demiris G, et al. Reactions to COVID-19, information and technology use, and social connectedness among older adults with pre-frailty and frailty. Geriatr Nurs 2021;42(1):188-195 [FREE Full text] [doi: 10.1016/j.gerinurse.2020.08.001] [Medline: $\underline{32863038}$ ]

53. Ciancio A, Kämpfen F, Kohler IV, Bennett D, Bruine de Bruin W, Darling J, et al. Know your epidemic, know your response: Early perceptions of COVID-19 and self-reported social distancing in the United States. PLoS One 2020;15(9):e0238341 [FREE Full text] [doi: 10.1371/journal.pone.0238341] [Medline: 32886671 ]

54. Daly M, Sutin AR, Robinson E. Depression reported by US adults in 2017-2018 and March and April 2020. J Affect Disord 2021 Jan 01;278:131-135 [FREE Full text] [doi: 10.1016/j.jad.2020.09.065] [Medline: 32956962]

55. Di Sebastiano KM, Chulak-Bozzer T, Vanderloo LM, Faulkner G. Don't Walk So Close to Me: Physical Distancing and Adult Physical Activity in Canada. Front Psychol 2020;11:1895 [FREE Full text] [doi: 10.3389/fpsyg.2020.01895] [Medline: $\underline{32849110]}$

56. Emerson K. Coping with being cooped up: Social distancing during COVID-19 among 60+ in the United States. Rev Panam Salud Publica 2020 Jun 29;44:e81 [FREE Full text] [doi: 10.26633/RPSP.2020.81] [Medline: 32612645]

57. Ettman CK, Abdalla SM, Cohen GH, Sampson L, Vivier PM, Galea S. Prevalence of Depression Symptoms in US Adults Before and During the COVID-19 Pandemic. JAMA Netw Open 2020 Sep 01;3(9):e2019686 [FREE Full text] [doi: 10.1001/jamanetworkopen.2020.19686] [Medline: 32876685]

58. Heid A, Cartwright F, Wilson-Genderson M, Pruchno R. Challenges Experienced by Older People During the Initial Months of the COVID-19 Pandemic. Gerontologist 2021 Jan 21;61(1):48-58 [FREE Full text] [doi: 10.1093/geront/gnaa138] [Medline: 32955079]

59. Holingue C, Badillo-Goicoechea E, Riehm K, Veldhuis C, Thrul J, Johnson R, et al. Mental distress during the COVID-19 pandemic among US adults without a pre-existing mental health condition: Findings from American trend panel survey. Prev Med 2020 Oct;139:106231 [FREE Full text] [doi: 10.1016/j.ypmed.2020.106231] [Medline: 32758507]

60. Islam J, Camacho-Rivera M, Vidot D. Examining COVID-19 Preventive Behaviors among Cancer Survivors in the United States: An Analysis of the COVID-19 Impact Survey. Cancer Epidemiol Biomarkers Prev 2020 Sep 25;29(12):2583-2590. [doi: 10.1158/1055-9965.epi-20-0801]

61. Knepple Carney A, Graf A, Hudson G, Wilson E. Age Moderates Perceived COVID-19 Disruption on Well-Being. Gerontologist 2021 Jan 21;61(1):30-35 [FREE Full text] [doi: 10.1093/geront/gnaa106] [Medline: 32808660]

62. Kotwal AA, Holt-Lunstad J, Newmark RL, Cenzer I, Smith AK, Covinsky KE, et al. Social Isolation and Loneliness Among San Francisco Bay Area Older Adults During the COVID-19 Shelter-in-Place Orders. J Am Geriatr Soc 2021 Jan;69(1):20-29 [FREE Full text] [doi: 10.1111/jgs.16865] [Medline: 32965024]

63. Krendl A, Perry BL. The Impact of Sheltering in Place During the COVID-19 Pandemic on Older Adults' Social and Mental Well-Being. J Gerontol B Psychol Sci Soc Sci 2021 Jan 18;76(2):e53-e58 [FREE Full text] [doi: 10.1093/geronb/gbaa110] [Medline: $\underline{\text { 32778899] }}$

64. Findlay LC, Arim R, Kohen D. Understanding the Perceived Mental Health of Canadians During the COVID-19 Pandemic. Health Rep 2020 Jun 24;31(4):22-27 [FREE Full text] [doi: 10.25318/82-003-x202000400003-eng] [Medline: 32644764]

65. Klaiber P, Wen J, DeLongis A, Sin NL. The Ups and Downs of Daily Life During COVID-19: Age Differences in Affect, Stress, and Positive Events. J Gerontol B Psychol Sci Soc Sci 2021 Jan 18;76(2):e30-e37 [FREE Full text] [doi: 10.1093/geronb/gbaa096] [Medline: $\underline{\text { 32674138] }}$ 
66. Mann FD, Krueger RF, Vohs KD. Personal economic anxiety in response to COVID-19. Pers Individ Dif 2020 Dec 01;167:110233 [FREE Full text] [doi: 10.1016/j.paid.2020.110233] [Medline: 32834283]

67. Nwachukwu I, Nkire N, Shalaby R, Hrabok M, Vuong W, Gusnowski A, et al. COVID-19 Pandemic: Age-Related Differences in Measures of Stress, Anxiety and Depression in Canada. Int J Environ Res Public Health 2020 Sep 01;17(17):6366 [FREE Full text] [doi: 10.3390/ijerph17176366] [Medline: 32882922]

68. Whatley MC, Siegel ALM, Schwartz ST, Silaj KM, Castel AD. Younger and Older Adults' Mood and Expectations Regarding Aging During COVID-19. Gerontol Geriatr Med 2020;6:2333721420960259 [FREE Full text] [doi: 10.1177/2333721420960259] [Medline: 32984443 ]

69. Whitehead B. COVID-19 as a Stressor: Pandemic Expectations, Perceived Stress, and Negative Affect in Older Adults. J Gerontol B Psychol Sci Soc Sci 2021 Jan 18;76(2):e59-e64 [FREE Full text] [doi: 10.1093/geronb/gbaa153] [Medline: $\underline{32886773}$ ]

70. Whitehead BR, Torossian E. Older Adults' Experience of the COVID-19 Pandemic: A Mixed-Methods Analysis of Stresses and Joys. Gerontologist 2021 Jan 21;61(1):36-47 [FREE Full text] [doi: 10.1093/geront/gnaa126] [Medline: 32886764]

71. Boschuetz N, Cheng S, Mei L, Loy VM. Changes in Alcohol Use Patterns in the United States During COVID-19 Pandemic. WMJ 2020 Sep;119(3):171-176 [FREE Full text] [Medline: 33091284]

72. Moen P, Pedtke J, Flood S. Disparate Disruptions: Intersectional COVID-19 Employment Effects by Age, Gender, Education, and Race/Ethnicity. Work Aging Retire 2020 Oct;6(4):207-228 [FREE Full text] [doi: 10.1093/workar/waaa013] [Medline: 33214905]

73. Ziliak JP. Food Hardship during the Covid-19 Pandemic and Great Recession. Appl Econ Perspect Policy 2020 Oct 02:10.1002/aepp.13099 [FREE Full text] [doi: 10.1002/aepp.13099] [Medline: $\underline{33042510}$ ]

74. Fong BYF, Wong MCS, Law VTS, Lo MF, Ng TKC, Yee HHL, et al. Relationships between Physical and Social Behavioural Changes and the Mental Status of Homebound Residents in Hong Kong during the COVID-19 Pandemic. Int J Environ Res Public Health 2020 Sep 12;17(18):6653 [FREE Full text] [doi: 10.3390/ijerph17186653] [Medline: $\underline{32932641]}$

75. Jiang W, Sun F, Prieto L, Fang Y, Gao Y, Yue L, et al. Worries, strategies, and confidence of older Chinese adults during the 2019 novel coronavirus outbreak. Int J Geriatr Psychiatry 2020 Dec;35(12):1458-1465. [doi: 10.1002/gps.5430] [Medline: 32909299]

76. Lee ATC, Mo FYM, Lam LCW. Higher psychogeriatric admissions in COVID-19 than in severe acute respiratory syndrome. Int J Geriatr Psychiatry 2020 Dec;35(12):1449-1457. [doi: 10.1002/gps.5422] [Medline: 32892460]

77. Li Q. Psychosocial and coping responses toward 2019 coronavirus diseases (COVID-19): a cross-sectional study within the Chinese general population. QJM 2020 Oct 01;113(10):731-738 [FREE Full text] [doi: 10.1093/qjmed/hcaa226] [Medline: 32678901]

78. Li Q, Miao Y, Zeng X, Tarimo CS, Wu C, Wu J. Prevalence and factors for anxiety during the coronavirus disease 2019 (COVID-19) epidemic among the teachers in China. J Affect Disord 2020 Dec 01;277:153-158 [FREE Full text] [doi: 10.1016/j.jad.2020.08.017] [Medline: 32828002]

79. Liu X, Luo W, Li Y, Li C, Hong Z, Chen H, et al. Psychological status and behavior changes of the public during the COVID-19 epidemic in China. Infect Dis Poverty 2020 May 29;9(1):58 [FREE Full text] [doi: 10.1186/s40249-020-00678-3] [Medline: 32471513]

80. Ping W, Zheng J, Niu X, Guo C, Zhang J, Yang H, et al. Evaluation of health-related quality of life using EQ-5D in China during the COVID-19 pandemic. PLoS One 2020;15(6):e0234850 [FREE Full text] [doi: 10.1371/journal.pone.0234850] [Medline: 32555642]

81. Qin F, Song Y, Nassis GP, Zhao L, Dong Y, Zhao C, et al. Physical Activity, Screen Time, and Emotional Well-Being during the 2019 Novel Coronavirus Outbreak in China. Int J Environ Res Public Health 2020 Jul 17;17(14):5170 [FREE Full text] [doi: 10.3390/ijerph17145170] [Medline: 32709003]

82. Sun Z, Yang B, Zhang R, Cheng X. Influencing Factors of Understanding COVID-19 Risks and Coping Behaviors among the Elderly Population. Int J Environ Res Public Health 2020 Aug 13;17(16):5889 [FREE Full text] [doi: 10.3390/ijerph17165889] [Medline: 32823740]

83. Tian F, Li H, Tian S, Yang J, Shao J, Tian C. Psychological symptoms of ordinary Chinese citizens based on SCL-90 during the level I emergency response to COVID-19. Psychiatry Res 2020 Jun;288:112992 [FREE Full text] [doi: 10.1016/j.psychres.2020.112992] [Medline: 32302816]

84. Wong SYS, Zhang D, Sit RWS, Yip BHK, Chung RY, Wong CKM, et al. Impact of COVID-19 on loneliness, mental health, and health service utilisation: a prospective cohort study of older adults with multimorbidity in primary care. Br J Gen Pract 2020 Sep 28;70(700):e817-e824. [doi: 10.3399/bjgp20x713021]

85. Zhang Y, Wang S, Ding W, Meng Y, Hu H, Liu Z, et al. Status and influential factors of anxiety depression and insomnia symptoms in the work resumption period of COVID-19 epidemic: A multicenter cross-sectional study. J Psychosom Res 2020 Nov;138:110253 [FREE Full text] [doi: 10.1016/j.jpsychores.2020.110253] [Medline: 32979696]

86. Zhao SZ, Wong JYH, Luk TT, Wai AKC, Lam TH, Wang MP. Mental health crisis under COVID-19 pandemic in Hong Kong, China. Int J Infect Dis 2020 Nov;100:431-433 [FREE Full text] [doi: 10.1016/j.ijid.2020.09.030] [Medline: 32947051] 
87. Antunes R, Frontini R, Amaro N, Salvador R, Matos R, Morouço P, et al. Exploring Lifestyle Habits, Physical Activity, Anxiety and Basic Psychological Needs in a Sample of Portuguese Adults during COVID-19. Int J Environ Res Public Health 2020 Jun 18;17(12):4360 [FREE Full text] [doi: 10.3390/ijerph17124360] [Medline: $\underline{32570737]}$

88. Arpino B, Pasqualini M, Bordone V, Solé-Auró A. Older People's Nonphysical Contacts and Depression During the COVID-19 Lockdown. Gerontologist 2021 Feb 23;61(2):176-186 [FREE Full text] [doi: 10.1093/geront/gnaa144] [Medline: 32977334]

89. Bäuerle A, Steinbach J, Schweda A, Beckord J, Hetkamp M, Weismüller B, et al. Mental Health Burden of the COVID-19 Outbreak in Germany: Predictors of Mental Health Impairment. J Prim Care Community Health 2020;11:2150132720953682 [FREE Full text] [doi: 10.1177/2150132720953682] [Medline: 32865107]

90. Bobes-Bascarán T, Sáiz PA, Velasco A, Martínez-Cao C, Pedrosa C, Portilla A, et al. Early Psychological Correlates Associated With COVID-19 in A Spanish Older Adult Sample. Am J Geriatr Psychiatry 2020 Dec;28(12):1287-1298 [FREE Full text] [doi: 10.1016/j.jagp.2020.09.005] [Medline: $\underline{\text { 32951996] }}$

91. Brooke J, Clark M. Older people's early experience of household isolation and social distancing during COVID-19. J Clin Nurs 2020 Nov;29(21-22):4387-4402. [doi: 10.1111/jocn.15485] [Medline: 32891063]

92. Bu F, Steptoe A, Fancourt D. Who is lonely in lockdown? Cross-cohort analyses of predictors of loneliness before and during the COVID-19 pandemic. Public Health 2020 Sep;186:31-34 [FREE Full text] [doi: 10.1016/j.puhe.2020.06.036] [Medline: 32768621]

93. Cagnin A, Di Lorenzo R, Marra C, Bonanni L, Cupidi C, Laganà V, SINdem COVID-19 Study Group. Behavioral and Psychological Effects of Coronavirus Disease-19 Quarantine in Patients With Dementia. Front Psychiatry 2020;11:578015 [FREE Full text] [doi: 10.3389/fpsyt.2020.578015] [Medline: 33033486]

94. Carriedo A, Cecchini JA, Fernandez-Rio J, Méndez-Giménez A. COVID-19, Psychological Well-being and Physical Activity Levels in Older Adults During the Nationwide Lockdown in Spain. Am J Geriatr Psychiatry 2020 Nov;28(11):1146-1155 [FREE Full text] [doi: 10.1016/j.jagp.2020.08.007] [Medline: 32919872]

95. Carson J, Prescott J, Allen R, McHugh S. Winter is coming: age and early psychological concomitants of the Covid-19 pandemic in England. JPMH 2020 Jul 27;19(3):221-230. [doi: 10.1108/jpmh-06-2020-0062]

96. Clotworthy A, Dissing A, Nguyen T, Jensen A, Andersen T, Bilsteen J, et al. 'Standing together - at a distance': Documenting changes in mental-health indicators in Denmark during the COVID-19 pandemic. Scand J Public Health 2021 Feb;49(1):79-87 [FREE Full text] [doi: 10.1177/1403494820956445] [Medline: 32907495]

97. García-Fernández L, Romero-Ferreiro V, López-Roldán PD, Padilla S, Rodriguez-Jimenez R. Mental Health in Elderly Spanish People in Times of COVID-19 Outbreak. Am J Geriatr Psychiatry 2020 Oct;28(10):1040-1045 [FREE Full text] [doi: 10.1016/j.jagp.2020.06.027] [Medline: 32718855]

98. García-Portilla P, de la Fuente Tomás L, Bobes-Bascarán T, Jiménez Treviño L, Zurrón Madera P, Suárez Álvarez M, et al. Are older adults also at higher psychological risk from COVID-19? Aging Ment Health 2020 Sep 01:1-8. [doi: 10.1080/13607863.2020.1805723] [Medline: 32870024]

99. Giebel C, Lord K, Cooper C, Shenton J, Cannon J, Pulford D, et al. A UK survey of COVID-19 related social support closures and their effects on older people, people with dementia, and carers. Int J Geriatr Psychiatry 2021 Mar;36(3):393-402 [FREE Full text] [doi: 10.1002/gps.5434] [Medline: 32946619]

100. Giustino V, Parroco A, Gennaro A, Musumeci G, Palma A, Battaglia G. Physical Activity Levels and Related Energy Expenditure during COVID-19 Quarantine among the Sicilian Active Population: A Cross-Sectional Online Survey Study. Sustainability 2020 May 26;12(11):4356. [doi: 10.3390/su12114356]

101. González-Sanguino C, Ausín B, Castellanos M, Saiz J, López-Gómez A, Ugidos C, et al. Mental health consequences during the initial stage of the 2020 Coronavirus pandemic (COVID-19) in Spain. Brain Behav Immun 2020 Jul;87:172-176 [FREE Full text] [doi: 10.1016/j.bbi.2020.05.040] [Medline: 32405150]

102. Górnicka M, Drywień ME, Zielinska MA, Hamułka J. Dietary and Lifestyle Changes During COVID-19 and the Subsequent Lockdowns among Polish Adults: A Cross-Sectional Online Survey PLifeCOVID-19 Study. Nutrients 2020 Aug 03;12(8):2324 [FREE Full text] [doi: 10.3390/nu12082324] [Medline: 32756458]

103. Graham A, Kremarik F, Kruse W. Attitudes of ageing passengers to air travel since the coronavirus pandemic. J Air Transp Manag 2020 Aug;87:101865 [FREE Full text] [doi: 10.1016/j.jairtraman.2020.101865] [Medline: $\underline{32834691]}$

104. Groarke J, Berry E, Graham-Wisener L, McKenna-Plumley P, McGlinchey E, Armour C. Loneliness in the UK during the COVID-19 pandemic: Cross-sectional results from the COVID-19 Psychological Wellbeing Study. PLoS One 2020;15(9):e0239698 [FREE Full text] [doi: 10.1371/journal.pone.0239698] [Medline: 32970764]

105. Gustavsson J, Beckman L. Compliance to Recommendations and Mental Health Consequences among Elderly in Sweden during the Initial Phase of the COVID-19 Pandemic-A Cross Sectional Online Survey. Int J Environ Res Public Health 2020 Jul 26;17(15):5380 [FREE Full text] [doi: 10.3390/ijerph17155380] [Medline: 32722624]

106. Haesebaert F, Haesebaert J, Zante E, Franck N. Who maintains good mental health in a locked-down country? A French nationwide online survey of 11,391 participants. Health Place 2020 Nov;66:102440 [FREE Full text] [doi:

10.1016/j.healthplace.2020.102440] [Medline: $\underline{32947185]}$ 
107. Hyland P, Shevlin M, McBride O, Murphy J, Karatzias T, Bentall RP, et al. Anxiety and depression in the Republic of Ireland during the COVID-19 pandemic. Acta Psychiatr Scand 2020 Sep;142(3):249-256. [doi: 10.1111/acps.13219] [Medline: $\underline{32716520]}$

108. Jacob L, Smith L, Butler L, Barnett Y, Grabovac I, McDermott D, et al. Challenges in the Practice of Sexual Medicine in the Time of COVID-19 in the United Kingdom. J Sex Med 2020 Jul;17(7):1229-1236 [FREE Full text] [doi: 10.1016/j.jsxm.2020.05.001] [Medline: 32411271]

109. Jia R, Ayling K, Chalder T, Massey A, Broadbent E, Coupland C, et al. Mental health in the UK during the COVID-19 pandemic: cross-sectional analyses from a community cohort study. BMJ Open 2020 Sep 15;10(9):e040620 [FREE Full text] [doi: 10.1136/bmjopen-2020-040620] [Medline: $\underline{\text { 32933965] }}$

110. Kivi M, Hansson I, Bjälkebring P. Up and About: Older Adults' Well-being During the COVID-19 Pandemic in a Swedish Longitudinal Study. J Gerontol B Psychol Sci Soc Sci 2021 Jan 18;76(2):e4-e9 [FREE Full text] [doi: 10.1093/geronb/gbaa084] [Medline: 32599622]

111. Li LZ, Wang S. Prevalence and predictors of general psychiatric disorders and loneliness during COVID-19 in the United Kingdom. Psychiatry Res 2020 Sep;291:113267 [FREE Full text] [doi: 10.1016/j.psychres.2020.113267] [Medline: $\underline{32623266]}$

112. López J, Perez-Rojo G, Noriega C, Carretero I, Velasco C, Martinez-Huertas J, et al. Psychological well-being among older adults during the COVID-19 outbreak: a comparative study of the young-old and the old-old adults. Int. Psychogeriatr 2020 May 22;32(11):1365-1370. [doi: 10.1017/s1041610220000964]

113. McAndrew J, O'Leary J, Cotter D, Cannon M, MacHale S, Murphy KC, et al. Impact of initial COVID-19 restrictions on psychiatry presentations to the emergency department of a large academic teaching hospital. Ir J Psychol Med 2020 Sep 30:1-8 [FREE Full text] [doi: 10.1017/ipm.2020.115] [Medline: 32996441]

114. Niedzwiedz C, Green M, Benzeval M, Campbell D, Craig P, Demou E, et al. Mental health and health behaviours before and during the initial phase of the COVID-19 lockdown: longitudinal analyses of the UK Household Longitudinal Study. J Epidemiol Community Health 2021 Mar;75(3):224-231 [FREE Full text] [doi: 10.1136/jech-2020-215060] [Medline: 32978210]

115. Ogden RS. The passage of time during the UK Covid-19 lockdown. PLoS One 2020;15(7):e0235871 [FREE Full text] [doi: 10.1371/journal.pone.0235871] [Medline: 32628735]

116. Ozamiz-Etxebarria N, Dosil-Santamaria M, Picaza-Gorrochategui M, Idoiaga-Mondragon N. Niveles de estrés, ansiedad y depresión en la primera fase del brote del COVID-19 en una muestra recogida en el norte de España. Cad. Saúde Pública 2020;36(4):e00054020. [doi: 10.1590/0102-311x00054020]

117. Parlapani E, Holeva V, Nikopoulou VA, Sereslis K, Athanasiadou M, Godosidis A, et al. Intolerance of Uncertainty and Loneliness in Older Adults During the COVID-19 Pandemic. Front Psychiatry 2020;11:842 [FREE Full text] [doi: 10.3389/fpsyt.2020.00842] [Medline: 32973584]

118. Parlapani E, Holeva V, Voitsidis P, Blekas A, Gliatas I, Porfyri GN, et al. Psychological and Behavioral Responses to the COVID-19 Pandemic in Greece. Front Psychiatry 2020;11:821 [FREE Full text] [doi: 10.3389/fpsyt.2020.00821] [Medline: 32973575]

119. Picaza Gorrochategi M, Eiguren Munitis A, Dosil Santamaria M, Ozamiz Etxebarria N. Stress, Anxiety, and Depression in People Aged Over 60 in the COVID-19 Outbreak in a Sample Collected in Northern Spain. Am J Geriatr Psychiatry 2020 Sep;28(9):993-998 [FREE Full text] [doi: 10.1016/j.jagp.2020.05.022] [Medline: 32576424 ]

120. Pieh C, Budimir S, Probst T. Corrigendum to "The effect of age, gender, income, work, and physical activity on mental health during coronavirus disease (COVID-19) lockdown in Austria" [Journal of Psychosomatic Research 136 (2020) 110186]. J Psychosom Res 2020 Dec;139:110278 [FREE Full text] [doi: 10.1016/j.jpsychores.2020.110278] [Medline: 33075602]

121. Pierce M, Hope H, Ford T, Hatch S, Hotopf M, John A, et al. Mental health before and during the COVID-19 pandemic: a longitudinal probability sample survey of the UK population. The Lancet Psychiatry 2020 Oct;7(10):883-892. [doi: 10.1016/s2215-0366(20)30308-4]

122. Pinto J, van Zeller M, Amorim P, Pimentel A, Dantas P, Eusébio E, et al. Sleep quality in times of Covid-19 pandemic. Sleep Med 2020 Oct;74:81-85 [FREE Full text] [doi: 10.1016/j.sleep.2020.07.012] [Medline: 32841849]

123. Rolland B, Haesebaert F, Zante E, Benyamina A, Haesebaert J, Franck N. Global Changes and Factors of Increase in Caloric/Salty Food Intake, Screen Use, and Substance Use During the Early COVID-19 Containment Phase in the General Population in France: Survey Study. JMIR Public Health Surveill 2020 Sep 18;6(3):e19630 [FREE Full text] [doi: 10.2196/19630] [Medline: 32589149]

124. Romero C, Delgado C, Catalá J, Ferrer C, Errando C, Iftimi A, et al. COVID-19 psychological impact in 3109 healthcare workers in Spain: The PSIMCOV group. Psychol. Med 2020 May 14:1-7. [doi: 10.1017/s0033291720001671]

125. Romito F, Dellino M, Loseto G, Opinto G, Silvestris E, Cormio C, et al. Psychological Distress in Outpatients With Lymphoma During the COVID-19 Pandemic. Front Oncol 2020;10:1270 [FREE Full text] [doi: 10.3389/fonc.2020.01270] [Medline: $\underline{32754447]}$ 
126. Smith L, Jacob L, Yakkundi A, McDermott D, Armstrong NC, Barnett Y, et al. Correlates of symptoms of anxiety and depression and mental wellbeing associated with COVID-19: a cross-sectional study of UK-based respondents. Psychiatry Res 2020 Sep;291:113138 [FREE Full text] [doi: 10.1016/j.psychres.2020.113138] [Medline: 32562931]

127. van der Velden PG, Contino C, Das M, van Loon P, Bosmans MW. Anxiety and depression symptoms, and lack of emotional support among the general population before and during the COVID-19 pandemic. A prospective national study on prevalence and risk factors. J Affect Disord 2020 Dec 01;277:540-548 [FREE Full text] [doi: 10.1016/j.jad.2020.08.026] [Medline: 32889378]

128. van Tilburg TG, Steinmetz S, Stolte E, van der Roest H, de Vries DH. Loneliness and mental health during the COVID-19 pandemic: A study among Dutch older adults. J Gerontol B Psychol Sci Soc Sci 2020 Aug 05:gbaa111 [FREE Full text] [doi: 10.1093/geronb/gbaa111] [Medline: 32756931]

129. Wang R, Helf C, Tizek L, Neuhauser R, Eyerich K, Zink A, et al. The Impact and Consequences of SARS-CoV-2 Pandemic on a Single University Dermatology Outpatient Clinic in Germany. Int J Environ Res Public Health 2020 Aug 26;17(17):6182 [FREE Full text] [doi: 10.3390/ijerph17176182] [Medline: 32858870]

130. Younger E, Smrke A, Lidington E, Farag S, Ingley K, Chopra N, et al. Health-Related Quality of Life and Experiences of Sarcoma Patients during the COVID-19 Pandemic. Cancers (Basel) 2020 Aug 14;12(8):2288 [FREE Full text] [doi: 10.3390/cancers12082288] [Medline: 32823999]

131. Constant A, Conserve DF, Gallopel-Morvan K, Raude J. Socio-Cognitive Factors Associated With Lifestyle Changes in Response to the COVID-19 Epidemic in the General Population: Results From a Cross-Sectional Study in France. Front Psychol 2020;11:579460 [FREE Full text] [doi: 10.3389/fpsyg.2020.579460] [Medline: 33132989]

132. Ferrante G, Camussi E, Piccinelli C, Senore C, Armaroli P, Ortale A, et al. Did social isolation during the SARS-CoV-2 epidemic have an impact on the lifestyles of citizens? Epidemiol Prev 2020;44(5-6 Suppl 2):353-362 [FREE Full text] [doi: 10.19191/EP20.5-6.S2.137] [Medline: 33412829]

133. Goethals L, Barth N, Guyot J, Hupin D, Celarier T, Bongue B. Impact of Home Quarantine on Physical Activity Among Older Adults Living at Home During the COVID-19 Pandemic: Qualitative Interview Study. JMIR Aging 2020 May 07;3(1):e19007 [FREE Full text] [doi: 10.2196/19007] [Medline: 32356777]

134. Hartley S, Colas des Francs C, Aussert F, Martinot C, Dagneaux S, Londe V, et al. The effects of quarantine for SARS-CoV-2 on sleep: An online survey. Encephale 2020 Jun;46(3S):S53-S59 [FREE Full text] [doi: 10.1016/j.encep.2020.05.003] [Medline: 32475692]

135. Heidinger T, Richter L. The Effect of COVID-19 on Loneliness in the Elderly. An Empirical Comparison of Pre-and Peri-Pandemic Loneliness in Community-Dwelling Elderly. Front Psychol 2020;11:585308 [FREE Full text] [doi: 10.3389/fpsyg.2020.585308] [Medline: 33101154]

136. Karatzias T, Shevlin M, Murphy J, McBride O, Ben-Ezra M, Bentall RP, et al. Posttraumatic Stress Symptoms and Associated Comorbidity During the COVID-19 Pandemic in Ireland: A Population-Based Study. J Trauma Stress 2020 Aug;33(4):365-370 [FREE Full text] [doi: 10.1002/jts.22565] [Medline: 32662129]

137. Rogers NT, Waterlow NR, Brindle H, Enria L, Eggo RM, Lees S, et al. Behavioral Change Towards Reduced Intensity Physical Activity Is Disproportionately Prevalent Among Adults With Serious Health Issues or Self-Perception of High Risk During the UK COVID-19 Lockdown. Front Public Health 2020;8:575091 [FREE Full text] [doi: 10.3389/fpubh.2020.575091] [Medline: $\underline{33102424]}$

138. Szabo A, Ábel K, Boros S. Attitudes toward COVID-19 and stress levels in Hungary: Effects of age, perceived health status, and gender. Psychol Trauma 2020 Sep;12(6):572-575. [doi: 10.1037/tra0000665] [Medline: 32744843]

139. Wammes J, Kolk MSc D, van den Besselaar Md JH, MacNeil-Vroomen Ph DJL, Buurman-van Es Rn BM, van Rijn Ph DM. Evaluating Perspectives of Relatives of Nursing Home Residents on the Nursing Home Visiting Restrictions During the COVID-19 Crisis: A Dutch Cross-Sectional Survey Study. J Am Med Dir Assoc 2020 Dec;21(12):1746-1750.e3 [FREE Full text] [doi: 10.1016/j.jamda.2020.09.031] [Medline: 33148480]

140. Stickley A, Matsubayashi T, Ueda M. Loneliness and COVID-19 preventive behaviours among Japanese adults. J Public Health (Oxf) 2020 Sep 03:fdaa151 [FREE Full text] [doi: 10.1093/pubmed/fdaa151] [Medline: 32880635]

141. Suzuki Y, Maeda N, Hirado D, Shirakawa T, Urabe Y. Physical Activity Changes and Its Risk Factors among Community-Dwelling Japanese Older Adults during the COVID-19 Epidemic: Associations with Subjective Well-Being and Health-Related Quality of Life. Int J Environ Res Public Health 2020 Sep 10;17(18):6591 [FREE Full text] [doi: 10.3390/ijerph17186591] [Medline: 32927829]

142. Yamada M, Kimura Y, Ishiyama D, Otobe Y, Suzuki M, Koyama S, et al. Effect of the COVID-19 Epidemic on Physical Activity in Community-Dwelling Older Adults in Japan: A Cross-Sectional Online Survey. J Nutr Health Aging 2020 Jun 23;24(9):948-950. [doi: 10.1007/s12603-020-1501-6]

143. Bergman Y, Cohen-Fridel S, Shrira A, Bodner E, Palgi Y. COVID-19 health worries and anxiety symptoms among older adults: the moderating role of ageism. Int. Psychogeriatr 2020 Jun 17;32(11):1371-1375. [doi: 10.1017/s1041610220001258]

144. Nimrod G. Changes in Internet Use When Coping With Stress: Older Adults During the COVID-19 Pandemic. Am J Geriatr Psychiatry 2020 Oct;28(10):1020-1024 [FREE Full text] [doi: 10.1016/j.jagp.2020.07.010] [Medline: $\underline{32771312]}$ 
145. Ring L, Greenblatt-Kimron L, Palgi Y. The moderating role of subjective nearness-to-death in the association between health worries and death anxieties from COVID-19. Death Stud 2020 Sep 22:1-6. [doi: 10.1080/07481187.2020.1821261] [Medline: $\underline{32960745]}$

146. Shrira A, Hoffman Y, Bodner E, Palgi Y. COVID-19-Related Loneliness and Psychiatric Symptoms Among Older Adults: The Buffering Role of Subjective Age. Am J Geriatr Psychiatry 2020 Nov;28(11):1200-1204 [FREE Full text] [doi: 10.1016/j.jagp.2020.05.018] [Medline: $\underline{32561276]}$

147. Barros MBA, Lima MG, Malta DC, Szwarcwald CL, Azevedo RCS, Romero D, et al. Report on sadness/depression, nervousness/anxiety and sleep problems in the Brazilian adult population during the COVID-19 pandemic. Epidemiol Serv Saude 2020;29(4):e2020427 [FREE Full text] [doi: 10.1590/s1679-49742020000400018] [Medline: $\underline{32844918}$ ]

148. de Maio Nascimento M. Covid-19: U3A students' report on the impacts of social isolation on physical and mental health and access to information about the virus during the pandemic. Educational Gerontology 2020 Jul 20;46(9):499-511. [doi: $10.1080 / 03601277.2020 .1795371]$

149. Malta DC, Szwarcwald C, Barros MBA, Gomes CS, Machado IE, Souza Júnior PRB, et al. The COVID-19 Pandemic and changes in adult Brazilian lifestyles: a cross-sectional study, 2020. Epidemiol Serv Saude 2020;29(4):e2020407 [FREE Full text] [doi: 10.1590/S1679-49742020000400026] [Medline: 32997069 ]

150. Werneck A, Silva D, Malta D, Souza-Júnior PRB, Azevedo L, Barros M, et al. Changes in the clustering of unhealthy movement behaviors during the COVID-19 quarantine and the association with mental health indicators among Brazilian adults. Transl Behav Med 2021 Mar 16;11(2):323-331 [FREE Full text] [doi: 10.1093/tbm/ibaa095] [Medline: 33021631 ]

151. Newby JM, O'Moore K, Tang S, Christensen H, Faasse K. Acute mental health responses during the COVID-19 pandemic in Australia. PLoS One 2020;15(7):e0236562 [FREE Full text] [doi: 10.1371/journal.pone.0236562] [Medline: 32722711 ]

152. Owen A, Tran T, Hammarberg K, Kirkman M, Fisher J. Poor appetite and overeating reported by adults in Australia during the coronavirus-19 disease pandemic: a population-based study. Public Health Nutr 2020 Sep 25;24(2):275-281. [doi: $10.1017 / \mathrm{s} 1368980020003833]$

153. Stanton R, To QG, Khalesi S, Williams SL, Alley SJ, Thwaite TL, et al. Depression, Anxiety and Stress during COVID-19: Associations with Changes in Physical Activity, Sleep, Tobacco and Alcohol Use in Australian Adults. Int J Environ Res Public Health 2020 Jun 07;17(11):4065 [EREE Full text] [doi: $\underline{10.3390 / i j e r p h 17114065}$ [ [Medline: $\underline{32517294]}$

154. Neill E, Meyer D, Toh WL, van Rheenen TE, Phillipou A, Tan EJ, et al. Alcohol use in Australia during the early days of the COVID-19 pandemic: Initial results from the COLLATE project. Psychiatry Clin Neurosci 2020 Oct;74(10):542-549 [FREE Full text] [doi: 10.1111/pcn.13099] [Medline: 32602150]

155. Doshi D, Karunakar P, Sukhabogi JR, Prasanna JS, Mahajan SV. Assessing Coronavirus Fear in Indian Population Using the Fear of COVID-19 Scale. Int J Ment Health Addict 2020 May 28:1-9 [FREE Full text] [doi: 10.1007/s11469-020-00332-X] [Medline: 32837422$]$

156. Venugopal VC, Mohan A, Chennabasappa LK. Status of mental health and its associated factors among the general populace of India during COVID-19 pandemic. Asia Pac Psychiatry 2020 Aug 24:e12412 [FREE Full text] [doi: 10.1111/appy.12412] [Medline: $\underline{\text { 32830876] }}$

157. Dai H, Zhang S, Looi K, Su R, Li J. Perception of Health Conditions and Test Availability as Predictors of Adults' Mental Health during the COVID-19 Pandemic: A Survey Study of Adults in Malaysia. Int J Environ Res Public Health 2020 Jul 30;17(15):5498 [FREE Full text] [doi: 10.3390/ijerph17155498] [Medline: 32751459]

158. Burhamah W, AlKhayyat A, Oroszlányová M, AlKenane A, Almansouri A, Behbehani M, et al. The psychological burden of the COVID-19 pandemic and associated lockdown measures: Experience from 4000 participants. J Affect Disord 2020 Dec 01;277:977-985 [FREE Full text] [doi: 10.1016/j.jad.2020.09.014] [Medline: 33065842]

159. Al Sulais E, Mosli M, AlAmeel T. The psychological impact of COVID-19 pandemic on physicians in Saudi Arabia: A cross-sectional study. Saudi J Gastroenterol 2020 Jun 04;26(5):249-255. [doi: 10.4103/sjg.sjg_174_20]

160. Cohen G, Russo M, Campos J, Allegri RF. COVID-19 Epidemic in Argentina: Worsening of Behavioral Symptoms in Elderly Subjects With Dementia Living in the Community. Front Psychiatry 2020;11:866 [FREE Full text] [doi: 10.3389/fpsyt.2020.00866] [Medline: 33005158]

161. Fernández RS, Crivelli L, Guimet NM, Allegri RF, Pedreira ME. Psychological distress associated with COVID-19 quarantine: Latent profile analysis, outcome prediction and mediation analysis. J Affect Disord 2020 Dec 01;277:75-84 [FREE Full text] [doi: 10.1016/j.jad.2020.07.133] [Medline: 32799107]

162. Canet-Juric L, Andrés ML, Del Valle M, López-Morales H, Poó F, Galli JI, et al. A Longitudinal Study on the Emotional Impact Cause by the COVID-19 Pandemic Quarantine on General Population. Front Psychol 2020;11:565688 [FREE Full text] [doi: 10.3389/fpsyg.2020.565688] [Medline: 33071893]

163. Ntsama Essomba MJ, Nzana V, Noubiap J, Zingui-Ottou M, Ciaffi L, Sobngwi E, et al. The Follow-Up and Well-Being of Geriatric Outpatients During COVID-19 Pandemic in Cameroon: Insights From the Yaounde Central Hospital. Gerontol Geriatr Med 2020;6:2333721420959242 [FREE Full text] [doi: 10.1177/2333721420959242] [Medline: 33029549]

164. Sorokin M, Kasyanov E, Rukavishnikov G, Makarevich O, Neznanov N, Lutova N, et al. Structure of anxiety associated with C OVID-19 pandemic: the online survey results. BRSMU 2020 Jun 2((3)2020):70-76. [doi: 10.24075/brsmu.2020.030]

165. Stylianou N, Samouti G, Samoutis G. Mental Health Disorders During the COVID-19 Outbreak in Cyprus. J Med Life 2020;13(3):300-305 [FREE Full text] [doi: 10.25122/jml-2020-0114] [Medline: $\underline{\text { 33072200] }}$ 
166. Krok-Schoen JL, Pisegna JL, BrintzenhofeSzoc K, MacKenzie AR, Canin B, Plotkin E, et al. Experiences of healthcare providers of older adults with cancer during the COVID-19 pandemic. J Geriatr Oncol 2021 Mar;12(2):190-195 [FREE Full text] [doi: 10.1016/j.jgo.2020.09.021] [Medline: $\underline{\text { 32978104] }}$

167. Pahayahay A, Khalili-Mahani N. What Media Helps, What Media Hurts: A Mixed Methods Survey Study of Coping with COVID-19 Using the Media Repertoire Framework and the Appraisal Theory of Stress. J Med Internet Res 2020 Aug 06;22(8):e20186 [FREE Full text] [doi: 10.2196/20186] [Medline: 32701459]

168. Beam C, Kim AJ. Psychological sequelae of social isolation and loneliness might be a larger problem in young adults than older adults. Psychol Trauma 2020 Aug;12(S1):S58-S60. [doi: 10.1037/tra0000774] [Medline: 32525372]

169. Eghtesadi M. Breaking Social Isolation Amidst COVID-19: A Viewpoint on Improving Access to Technology in Long-Term Care Facilities. J Am Geriatr Soc 2020 May;68(5):949-950 [FREE Full text] [doi: 10.1111/jgs.16478] [Medline: 32277470]

170. Previtali F, Allen L, Varlamova M. Not Only Virus Spread: The Diffusion of Ageism during the Outbreak of COVID-19. J Aging Soc Policy 2020;32(4-5):506-514. [doi: 10.1080/08959420.2020.1772002] [Medline: 32507060]

171. Fraser S, Lagacé M, Bongué B, Ndeye N, Guyot J, Bechard L, CCNA Social InclusionStigma Working Group, et al. Ageism and COVID-19: what does our society's response say about us? Age Ageing 2020 Aug 24;49(5):692-695 [FREE Full text] [doi: 10.1093/ageing/afaa097] [Medline: $\underline{\text { 32377666] }}$

172. Meisner BA. Are You OK, Boomer? Intensification of Ageism and Intergenerational Tensions on Social Media Amid COVID-19. Leisure Sciences 2020 Jun 24:1-6. [doi: 10.1080/01490400.2020.1773983]

173. Jimenez-Sotomayor MR, Gomez-Moreno C, Soto-Perez-de-Celis E. Coronavirus, Ageism, and Twitter: An Evaluation of Tweets about Older Adults and COVID-19. J Am Geriatr Soc 2020 Aug 09;68(8):1661-1665 [FREE Full text] [doi: 10.1111/jgs.16508] [Medline: 32338787]

174. Bilal A, Saeed M, Yousafzai T. Elderly care in the time of coronavirus: Perceptions and experiences of care home staff in Pakistan. Int J Geriatr Psychiatry 2020 Dec;35(12):1442-1448 [FREE Full text] [doi: 10.1002/gps.5386] [Medline: 32748399]

175. Vaitheswaran S, Lakshminarayanan M, Ramanujam V, Sargunan S, Venkatesan S. Experiences and Needs of Caregivers of Persons With Dementia in India During the COVID-19 Pandemic-A Qualitative Study. Am J Geriatr Psychiatry 2020 Nov;28(11):1185-1194 [FREE Full text] [doi: 10.1016/j.jagp.2020.06.026] [Medline: 32736918]

176. Hwang T, Rabheru K, Peisah C, Reichman W, Ikeda M. Loneliness and social isolation during the COVID-19 pandemic. Int Psychogeriatr 2020 Oct;32(10):1217-1220 [FREE Full text] [doi: 10.1017/S1041610220000988] [Medline: 32450943 ]

177. van Dyck LI, Wilkins KM, Ouellet J, Ouellet GM, Conroy ML. Combating Heightened Social Isolation of Nursing Home Elders: The Telephone Outreach in the COVID-19 Outbreak Program. Am J Geriatr Psychiatry 2020 Sep;28(9):989-992 [FREE Full text] [doi: 10.1016/j.jagp.2020.05.026] [Medline: 32593495]

178. Office EE, Rodenstein MS, Merchant TS, Pendergrast TR, Lindquist LA. Reducing Social Isolation of Seniors during COVID-19 through Medical Student Telephone Contact. J Am Med Dir Assoc 2020 Jul;21(7):948-950 [FREE Full text] [doi: 10.1016/j.jamda.2020.06.003] [Medline: 32674825]

179. Gould CE, Hantke NC. Promoting Technology and Virtual Visits to Improve Older Adult Mental Health in the Face of COVID-19. Am J Geriatr Psychiatry 2020 Aug;28(8):889-890 [FREE Full text] [doi: 10.1016/j.jagp.2020.05.011] [Medline: 32425468]

180. Banskota S, Healy M, Goldberg E. 15 Smartphone Apps for Older Adults to Use While in Isolation During the COVID-19 Pandemic. West J Emerg Med 2020 Apr 14;21(3):514-525 [FREE Full text] [doi: 10.5811/westjem.2020.4.47372] [Medline: $\underline{32302279]}$

181. van Dijk SDM, Bouman R, Folmer EH, den Held RC, Warringa JE, Marijnissen RM, et al. (Vi)-rushed Into Online Group Schema Therapy Based Day-Treatment for Older Adults by the COVID-19 Outbreak in the Netherlands. Am J Geriatr Psychiatry 2020 Sep;28(9):983-988 [FREE Full text] [doi: 10.1016/j.jagp.2020.05.028] [Medline: 32622730]

182. Damiot A, Pinto A, Turner J, Gualano B. Immunological Implications of Physical Inactivity among Older Adults during the COVID-19 Pandemic. Gerontology 2020;66(5):431-438 [FREE Full text] [doi: 10.1159/000509216] [Medline: 32585674]

183. Vagetti GC, Barbosa Filho VC, Moreira NB, Oliveira VD, Mazzardo O, Campos WD. Association between physical activity and quality of life in the elderly: a systematic review, 2000-2012. Braz J Psychiatry 2014;36(1):76-88 [FREE Full text] [doi: 10.1590/1516-4446-2012-0895] [Medline: 24554274]

184. Roschel H, Artioli G, Gualano B. Risk of Increased Physical Inactivity During COVID-19 Outbreak in Older People: A Call for Actions. J Am Geriatr Soc 2020 Jun;68(6):1126-1128. [doi: 10.1111/jgs.16550] [Medline: 32392620]

185. Brooke J, Jackson D. Older people and COVID-19: Isolation, risk and ageism. J Clin Nurs 2020 Jul;29(13-14):2044-2046. [doi: 10.1111/jocn.15274] [Medline: 32239784]

186. Guo Y, Cheng C, Zeng Y, Li Y, Zhu M, Yang W, et al. Mental Health Disorders and Associated Risk Factors in Quarantined Adults During the COVID-19 Outbreak in China: Cross-Sectional Study. J Med Internet Res 2020 Aug 06;22(8):e20328 [FREE Full text] [doi: 10.2196/20328] [Medline: $\underline{\text { 32716899] }}$

187. Constandt B, Thibaut E, De Bosscher V, Scheerder J, Ricour M, Willem A. Exercising in Times of Lockdown: An Analysis of the Impact of COVID-19 on Levels and Patterns of Exercise among Adults in Belgium. Int J Environ Res Public Health 2020 Jun 10;17(11):4144 [FREE Full text] [doi: 10.3390/ijerph17114144] [Medline: $\underline{32532013}$ ] 
188. Maarefvand M, Hosseinzadeh S, Farmani O, Safarabadi Farahani A, Khubchandani J. Coronavirus Outbreak and Stress in Iranians. Int J Environ Res Public Health 2020 Jun 20;17(12):4441 [FREE Full text] [doi: 10.3390/ijerph17124441] [Medline: $\underline{32575763]}$

189. Henning-Smith C. The Unique Impact of COVID-19 on Older Adults in Rural Areas. J Aging Soc Policy 2020;32(4-5):396-402. [doi: 10.1080/08959420.2020.1770036] [Medline: $\underline{32475255]}$

190. Park J. Unraveling the Invisible but Harmful Impact of COVID-19 on Deaf Older Adults and Older Adults with Hearing Loss. J Gerontol Soc Work 2020;63(6-7):598-601. [doi: 10.1080/01634372.2020.1799282] [Medline: 32744477]

\title{
Abbreviations \\ HDM-DCP: Human Development Model-Disability Creation Process \\ PRISMA: Preferred Reporting Items for Systematic Reviews and Meta-analyses
}

\author{
Edited by J Wang; submitted 16.12.20; peer-reviewed by K Acquaviva, H LaMonica; comments to author 02.02.21; revised version \\ received 07.03.21; accepted 10.03.21; published 12.04 .21 \\ Please cite as: \\ Lebrasseur A, Fortin-Bédard N, Lettre J, Raymond E, Bussières EL, Lapierre N, Faieta J, Vincent C, Duchesne L, Ouellet MC, Gagnon \\ E, Tourigny A, Lamontagne ME, Routhier $F$ \\ Impact of the COVID-19 Pandemic on Older Adults: Rapid Review \\ JMIR Aging 2021;4(2):e26474 \\ URL: https://aging.jmir.org/2021/2/e26474 \\ doi: $\underline{10.2196 / 26474}$ \\ PMID: 33720839
}

(C)Audrey Lebrasseur, Noémie Fortin-Bédard, Josiane Lettre, Emilie Raymond, Eve-Line Bussières, Nolwenn Lapierre, Julie Faieta, Claude Vincent, Louise Duchesne, Marie-Christine Ouellet, Eric Gagnon, André Tourigny, Marie-Ève Lamontagne, François Routhier. Originally published in JMIR Aging (http://aging.jmir.org), 12.04.2021. This is an open-access article distributed under the terms of the Creative Commons Attribution License (https://creativecommons.org/licenses/by/4.0/), which permits unrestricted use, distribution, and reproduction in any medium, provided the original work, first published in JMIR Aging, is properly cited. The complete bibliographic information, a link to the original publication on http://aging.jmir.org, as well as this copyright and license information must be included. 